\title{
Erranaldiko elementuen ordena euskaraz: Lehen Hezkuntzako irakasle-gaiek zer hobetsi duten eta zergatik ${ }^{1}$
}

\author{
Julian Maia-Larretxea \\ (UPV/EHU-DREAM taldea) \\ julian.maia@ehu.eus
}

Hizkuntzaren eta Literaturaren Didaktika Bilboko Irakasleen Unibertsitate Eskola Euskal Herriko Unibertsitatea UPV/EHU

DOI: http://dx.doi.org/10.1387/tantak.19159

GAKO-HITZAK: Euskara, prosa idatzia, hitz-ordena, atzerakarga, azterketa enpirikoa, Lehen Hezkuntza.

\section{SARRERA: IKERKETAREN MARKOA}

Euskarak azken mende erdian (1965-2015) aukera izan du esparru formal batzuetan erabilia izaten hasteko eta horrenbertzez eremu horietan garatzeko, lehenago ez baitu inoiz ere izan hartarako egokiera erosorik batere. Azken urte hauetan, horrela, eskarmentu polita izan dugu hiztunok lehenago landu gabeko alorretan euskara baliatzeko eta lan horietan euskarazko prosa idatzia eraikitzeko. Hala ere, inguruan ditugun hizkuntza indartsuen aldean, erran daiteke euskarak orainik pauso batzuk bertzerik ez dituela egin, eta ongi bizkortzeko eta zaulitzeko baduela bidea egin beharra. Hala dio Juan Garziak 2014ko lanean euskara nola dagoen eta bidean non den bere garapenean:

«[...] Ahozkotasun txirotik irten berri den eta oraindik ere idatziaren formaltasunean finkatzeko arazoak dituen hizkuntza batean, horretan baitago gurea.» (Garzia, 2014: 38)

${ }^{1}$ Artikulu honen oinarrian den ikerketak UPV/EHUren laguntza izan du, EHU14/26 kodeko proiektuaren bidez. 
Asentatu-falta hori izanen da segur aski arrazoi bat zergatik erakusten dugun euskaldunok hainbertzeko interesa edo kezka euskarak zenbateraino ote duen garatua bere komunikazio-gaitasuna. Arrangura horren adierazgarri dira, bertzeak bertze, azken urteotan argitaratu diren hainbat lan, hala nola Joxe Ramon Zubimendi eta Pello Esnalen Idazkera-liburua (1993), Bittor Hidalgoren Hitzen ordena euskaraz (1995) eta Hitzen ordena esaldian (2002), Jesus Rubioren Euskararen garabideak (2002), Mitxel Kaltzakortaren Prosa komunikagarriago egiten: zenbait proposamen (2007) eta Zelan ordenatu egoki informazioa testuetan-I (2012), Xabier Aristegietaren Euskarazko testuen komunikagarritasun-problema larriak (2009), Pello Esnalek taxutu eta koordinatu Hitz-ordena. Erabilera estrategikoa (2011), edo Xabier Amurizaren Euskara Batuaren bigarren jaiotza (2010) eta Zazpi ebidentzia birjaiotzarako (2012), Jesus Mari Agirreren ekarpen llabur baina bixigarria atzendu gabe, Estilo jarraituaren alde (2013), edo berrikiago, Mikel Mendizabalen Hizkuntzen berdintasun komunikatiboa: mitoa ala errealitatea?, 2014an argitaratua, edo baita Juan Garziaren Esaldiaren antolaera. Funtzio informatikoak gako (2014), edo Kepa Altonagaren lana Back to Leizarraga (2015). Aipatzekoa da, segurki, Ibon Sarasolak 2016an argitaratu duen Bitakora kaiera, non Leizarragara itzuli beharraz gainera Altubetik ihes egin beharra aldarrikatzen den. Ikuspuntu desberdinetatik ari dira egileak lan horietan, baina denetan ageri dira arrangurak egungo prosa idatziaren egoerari buruz, eta baita orobat proposamenak edo kezkak zer norabide hartu beharko lukeen euskarak indartsu garatzeko esparru formal erdietsi-berrisamar horietan.

Kezka-ildo berean koka ditzakegu halaber hainbat egilek egin dituzten iradokizunak edo proposamenak euskararen prosa garatzeko nola-eta komunikazioaren ikuspuntutik efizientea izanen den eredu baten arabera. Egile horietako batzuk aipatuak dira lehengo saio batean (Maia, 2014), eta geroztik gai horren inguruko lanen zerrenda handitzen ari da.

Egile horien aztergaiak eta ikuspegiak ez dira denak bat, baina kezkagai diren puntuetan nabaritzeko gisan agertzen da euskararen hitz-ordena delakoa: alegia, bertzeak bertze, tratatzen den aferetako bat da euskarazko erranaldietako elementuak nola ordenatu beharko genituzkeen haien bidez garatzeko prosa idatzi bat aski egokia litzatekeena gaur egungo euskaldunen komunikazio-beharrak asetzeko, bereziki prosa logiko-diskurtsiboaren eremuan, non euskara erlatiboki gutxi erabili den, zeren esparru formal nagusietan sarbide txikia izan baitu azken mende erdi honetara bitartean (hala nola administrazioan, komunikabideetan eta hezkuntzaren eremuan). Euskara testuinguru berri horietan egokitu eta trebatu beharrari erantsi behar zaio gaur egun mundu gero eta eleaniztunago batean bizi garela, eta horrek erran nahi duela gero eta hiztun euskaldun gehiagok eskura izanen dituela orobat bertze hizkuntza indartsu batzuk eta oso ongi garatuak, esparru formaleko zeregin aunitzetarako. 
Euskararen hitz-ordenaren gaiarekin lotua berehala agertzen da atzerakargaren kontzeptua. Atzerakarga, arazo gisa, aurreko mendearen azken urteetan agertu zen garbiro azaldua (Zubimendi \& Esnal, 1993). Ezaugarri hori zenbaitetan euskararen bere-berezko ezaugarritzat hartu izan da, oinarrizko hitz-ordena neutrotzat SOV hartu ohi baita, eta hurrenkera hori erranaldi guzietara hedatzetik dator haren ondorio kasik «natural» gisa aditza atzera eramatea eta beraz atzerakarga handiaren izana. Halere azken urteotako ekarpen batzuetan nabari da ezaugarri tipologiko horri ez zaiola ematen kategoria zertako-eta hura bakarra izateko gidalerro eztabaidatu-ezina euskarazko orotariko eta orotaratzeko prosa idatzia garatzeko.

\subsection{Aferaren nondik norako nagusia, denboraren joanean}

Euskarazko erranaldiko elementuen antolamenduaz egin diren proposamenetan, azken mende guzia kontuan hartuta, modu eskematikoan 3 joera nagusi bereizi izan dira euskarazko prosa garatzeko eredu gisa: 1) Eredu idealista-idiosinkratikoa, haren ordezkari nabariena delarik Erderismos liburuan 1929an proposaturiko norabidea (Altube, 1975 [1929]); eredu haren ondotikoak izan dira nagusi Xx. mendearen azken laurdenean euskara normalizatzeko ahalegin handia abiatu zenean eta ondoko urteetan; 2) lasterka («karrakailuka») homologatzeko eredua, Jesus Rubio (2002) delarik formulazio muturreko horren sortzailea eta defendatzaile nagusia; eta 3) arian-ariko egokitze doitu eta haztatua izeneko eredua, azken honetan sartzen direlarik hainbat egileren proposamenak, batzuk xeheagoak eta bertze batzuk orotarakoak-edo izan nahi dutenak (Maia, 2014).

Eredu idealista-idiosinkratiko deituriko jokabidea gertatu zen nagusi euskararen normalizazio-prozesua hasi zenean joan den mendearen azken herenean (Mitxelena, 2011 [1981]). Eredu horrek hitz-ordenari buruz planteatzen dituen irizpide nagusi batzuk honela formula daitezke: 1) erranaldietan galdegaia izaten da informazio elementurik garrantzitsuena eta hura jartzen da aditzaren aitzin-aitzinean; 2) aditza erranaldiaren amaieran jarri behar $\mathrm{da}^{2}$; 3) menpeko perpausak aditz nagusiaren aurretik jarri behar dira; 4) menpekotasuna adierazteko elementuak mendeko perpausaren amaieran jarri behar dira (ikus Maia, 2015b).

Lasterka homologatzeko joeraren kezka nagusietako bat da aurkitu behar direla elementu egokiak prosa garatzeko, hain zuzen ere inspirazioa

\footnotetext{
2 Aditza amaieran jarri behar delako hori ez da zehazki erraten Erderismos lanean, baina liburu horretan egiten den proposamenen edo gomendioen sarean aditza hartara biltzera «behartua» edo «bulkatua» gertatzen da.
} 
bilatuta gure inguruan ditugun hizkuntza erabilienetan eta garatuenetan (gaztelanian, frantsesean eta ingelesean) edo zuzenean haiei kopiatuta. Jokabide horren azpian dagoen hasierako eta funtsezko sinesmena da euskara azpigaratua dagoela bai sintaktikoki eta bai komunikazioaren ikuspuntutik, eta egoera hori zuzentzeko eta konpontzeko bide bakarra dela imitatzea gure inguruko bertze hizkuntza indartsuenen aribideak, haiek baitira prosa idatziaren garapen-bidean haratena joan direnak, hartarako (omen) den bide bakarrean barna. Testuinguru horretan proposatzen da baliabide prepositibo arrotz batzuk sortzea/asmatzea eta baliatzea, bertzeak bertze (ikus Rubio, 2002).

Hirugarren eredutzat hartzen dugu arian-ariko egokitze doitua eta haztatua erraten dioguna. Jokaera horretakotzat jo daitezkeen ezaugarri batzuk hauexek dira: 1) tradizioaren ikuspegi osoa hartzen da kontuan; 2) ez da irizpide murrizgarririk edo debekatzailerik bertze hizkuntzetan (ere) garatu diren hizkuntza-baliabideak errefusatzeko edo gutxiesteko; 3) komunikazioaren alderdiari ematen zaio lehentasuna hizkuntza-baliabideak hautatzeko orduan, eta ez hizkuntzaren balizko edo egiazko berezitasunari edo bertzeekiko desberdintasunari; 4) atzerakarga (gehiegizkoa), testuinguru horretan, kaltegarritzat jotzen da eta hura txikitzeko proposamenak egiten dira.

Gure ustez azkeneko urteotan aldaketa bat gertatzen ari da gai honetan maila teorikoan edo/eta adituen mailan. Joan den mendean eredu idealistaidiosinkratikoa baldin bazen erreferentziako joera, azken urteotako ekarpenetan nabari da isuria atzerakarga txikitzeko eta, oro har, erranen genuke indarra irabazten ari dela arian-ariko egokitze doitu eta haztatuko jarrera (Maia, 2014).

\subsection{Atzerakargaren inguruan}

Goian erran dugu ezen euskararen normalizazio-prozesua bizkor abiatu zenean Xx. mendearen azken laurdenean, eredu idealista-idiosinkratikoa erran dioguna hartu zela eredu nagusitzat euskarazko prosa garatzeko. Gogora dezagun prosa horrek lau ezaugarri nagusi zituela, goian erran ditugunak, eta arau edo orientabide haiei jarraituz eginiko/eraikiriko prosa kontsideratzen zela ereduzkoa eta euskarari zegokion benetako garabidea.

Baina, kontua da komunikazio-arazoa gertatzen dela prosa idatzian hain zuzen ere arau horiek batera aplikatu nahi direnean tinko-tinko, erranaldi laburretan bezala luzeagoetan ere berdin: horrela eraikiriko prosa maiz gertatzen da atzerakarga handiko erranaldiz zamatua, horrek komunikazio efizientziari dakarzkion ondorioekin.

Zehaztu dezagun zeri erraten zaion atzerakarga. Kontzeptu hori zer den azaltzeko saio desberdinak izan dira. Zubimendik eta Esnalek (1993: 171) hura esplikatzen hastean honela diote: «Atzerakarga. Auzoko erdarek 
ez bezala, euskarak atzean eramaten du askotan mezuaren giltza». Ikuspegi horretan, atzerakarga da euskararen ezaugarri bat, konnotazio positiborik edo negatiborik gabea, hizkuntzaren ezaugarri baten konstatazio bat bezala (nahiz eta gero, arazoak identifikaturik, bideak eskaintzen diren atzerakargak ekar ditzakeen problemak konpontzeko).

Kaltzakortak (2007), berriz, honela dio: «Hona hemen zer ulertzen dugun alperreko karga edo atzerakargatzat perpaus barruan: desegoki sekuentziatzea osagai bi, zehatzago esateko, informazio-osagarri bat alperrik erabiltzea informazio-gunearen aurrean, oztopo egiten duela ondo eta erraz irakurtzeko (beraz, arazo informatiboa)» (Kaltzakorta, 2007: 7). Eta geroago, atzerakarga ulerturik arazo gisa, eta beraz konpondu beharrekotzat: «[...] proposatu gura dugu atzerakargaren eskema (osagarria + GUNEA) atzekoz aurrera ematea (GUNEA + Osagarria)».

Guk atzerakarga definituko genuke erranez efektu hori gertatzen dela noiz-eta mezua prozesatzeko eta ulertzeko giltzarri diren elementu batzuk jartzen direnean erranaldiaren amaiera aldera, hartara mezuaren ulerkuntza gibelatuz eta zailduz. Definizio hau ere ikus daiteke (Maia, 2015b): atzerakarga da fenomeno bat gertatzen dena erranaldiko elementu batzuk, funtsezkoak direnak mezua gradualki prozesatzeko, jartzen direnean erranaldiaren atzeko aldean eta horrela gibelatzen eta zailtzen denean mezuaren prozesamendua ${ }^{3}$.

Ikus dezagun, adibide bat baliatuta, zer erran nahi dugun, aztergai harturik perpaus bat, gero azalduko dugun ikersaioan erabili genuena.

Demagun baditugula bi erranaldi, 1a) eta 1b), elementu berak dituztenak baina hurrenkera desberdinetan antolatuak:

1a) Konpetentzien bidezko planteamenduak eskatzen du etengabe mugitzea konpetentzia orokorretatik berezietara eta haietatik operatiboetara.

1b) Konpetentzien bidezko planteamenduak, konpetentzia orokorretatik berezietara eta haietatik operatiboetara etengabe mugitzea eskatzen du.

Erranaldi horiek ez ditugu laburrak kontsideratzen, baina ez dira oso luzeak ere; ez dira erranaldi xinpleak, baina ez dira oso bihurriak edo konplexuak ere. Bertzalde, aditz nagusia lehenago jarri baita 1a)-n, antolamendu hori jotzen dugu atzerakarga edo gibelkarga txikiagokotzat; 1b) erranaldiak gibelkarga handiagoa du, hain zuzen ere aditz nagusiaren posizioa atzerago/gibelago jarria delakoz.

Konpara dezagun zer posiziotan dagoen erranaldi horien aditz nagusia. Onartuko dugu, hasieratik, aditza funtsezko elementu bat dela mezua

\footnotetext{
3 Gure testuan batzuetan atzerakarga erraten diogu izatez «atzerakarga handia edo handiegia» dei dakiokeenari (laburrago jokatzeko).
} 
behar bezala ulertzeko, zeren hain zuzen ere hark bideratu ohi baitu erranaldi guziaren eduki informatiboaren zati garrantzitsuenetako bat. Hortik abiatuta, lehenbiziko erranaldian 15 . silaba da aditzaren hasierako posizioa; bigarren hurrenkeran, ordea, 1b) izeneko erranaldian, aditzaren hasiera gibelatu egin da 54. silabaraino ${ }^{4}$. Hau da: 39 silaba geroago ematen da aditz nagusia bigarren hurrenkera erabiltzen badugu, hots, 1b) antolamendua hautatzen baldin badugu. Aditza horrenbertze silaba geroago emanez gero iduri du irakurleak arazo gehiago izanen duela bigarren erranaldia prozesatzeko eta ulertzeko, zeren aditz nagusiak dakarren karga semantiko-informatiboa aurkeztea atzeratu egiten baita 39 silabaz, eta bitartean irakurleak gogoan eduki behar baitu gainerako informazio guzia zeren aditz nagusiak ematen duen gakoa ezin erabili baitu hura agertzen den arte amaiera-amaieran.

Erran dugu erranaldi hori aztertu genuela, bertze batzuen artean, gure ikersaioan. Emaitza izan zen inkestatuen \%93k aditzera eman zuela nahiago zuela atzerakarga handieneko hurrenkera; erantzun zutenen $\% 7 \mathrm{k}$ bertzerik ez zuten hobetsi 1a) erranaldiaren antolamendua, nahiz eta aunitzez ere gibelkarga txikiagokoa izan. Bertzela erranik: gibelkarga handieneko hitz-ordena hobetsi zuten inkestatu gehien-gehienek. Ez dugu uste adibidean hobetsi den jokabide hori denik modurik hoberena euskarazko prosa garatzeko, izan ere atzerakarga handiagoak mezuaren ulermena zaildu egiten baitu eta maiz behartzen baitu erranaldia berriz irakurtzera. Gure iduriko, jokamolde hori indartzearen onura are dudazkoagoa da kontuan hartzen badugu inguruan eleaniztasuna hazten joanen dela ondoko urteetan, eta euskarak bere tokia bilatu beharko duela nolabaiteko bizikidetzan edo/eta lehian bertze hizkuntza batzuekin.

\section{IKERKETAREN TESTUINGURUAZ ETA METODOAZ}

Prosa logiko-diskurtsiboa garatzeko, erranaldiko elementuen ordena ezinbertzean zaindu beharreko puntua da, gure ustez hori erabakigarria gertatzen baita prosa bat garatzeko efizientea, on izanen dena jendarte eleaniztunean ideiak arin eta zauli adierazteko, eta horrela «lehian» aritzeko inguruan diren hizkuntza indartsuekin. Alor horretan ekarpen teorikoetan bilakaera gertatzen ari dela uste dugu, eta uste dugu orobat ekarpen berri horien ondorioek nolabaiteko isla behar du-

4 Atzerakargaren zenbatekoa neurtzeko edo adierazteko, hemen silaba hartzen dugu unitate. Ez dugu horrekin erraten silaba dela parametro egokiena atzerakargaren afera bere osoan aztertzeko. Ohartzen gara silaba ez ezik hitza ere erabil zitekeela neurri gisa, edo baita sintagma ere. Halere, bai uste dugu silaba parametro baliagarria dela aztertu nahi den fenomenoaren berri emateko, nahiz eta badituen bere alde onak bezala txarrak ere. 
tela hezkuntza-sisteman ikas-irakasten den prosa-ereduan. Kontuan harturik hezkuntza-sistemako irakasleen jarrera determinantea dela zehazteko hurrengo belaunaldiek nolako prosa logiko-diskurtsiboa erabiliko duten, biziki garrantzitsua da jakitea zer iritzi eta irizpide ageri diren hezkuntza-sistemako irakasleen artean. Ildo horretan sartzen da ikerketa-saio hau.

Ikerketa ildo honetan dagoeneko badira lan batzuk eginak. Badira konparazioak eginak ikusteko nolako irizpideak baliatzen dituzten kolektibo desberdin batzuek. Alde batetik, bada azterketa bat egina ikusteko zer joera erakusten dituen aditu talde batek, 8 kidez osatua eta goi-mailako gaitasunekoa prosa logiko-diskurtsibo idatzian (hemendik aitzinera, talde horretakoei hizkuntzalari adituak deituko diegu); bertzetik, berriz, arakatu izan da nolako jokabidea baliatzen duten ikasle batzuek, ari direnak euskaraz ikasten Lehen Hezkuntzako Gradua unibertsitatean. Bi azterketa horien emaitzak konparatuta ikusten da unibertsitateko ikasleen taldeak askoz ere joera handiagoa duela atzerakarga handiko hurrenkerak hobesteko, eta horrenbertzez iduri du jarrera idealista-idiosinkratikoaren isla indartsu nabari dela haien jardunean (edo zehazkiago errateko, haien irizpideetan). Aldiz, hizkuntzalari adituen kasuan, atzerakarga txikiagoko hurrenkerek harrera franko hobea jaso dute (ikus Maia \& Larrea, 2013; Maia, 2015a, 2015b). Hori koherentea da lehen aipatu dugun norabidearekin, interpretazio-bide hau baliatuta: ikerketetako datu konparatuak ikusita pentsa liteke gure ikerketako hizkuntzalari adituek irizpide «eguneratuagoak» bide dituztela erranaldiko elementuen ordenari buruz. Hau da, aditu horientzat jarrera idealista-idiosinkratikoaren eragina txikiagoa litzateke ezen ez azterturiko ikasle unibertsitarioentzat.

Ikersaio hau ildo horretan ari da aitzinera-nahian: alde batetik, datu osagarriak aurkitu nahi dira ea zer ordenamendu hobesten duten unibertsitateko ikasleen lagin bateko kideek (Lehen Hezkuntzako irakasle izateko hasierako prestakuntza jasotzen ari direnak), eta bertzetik informazioa erdietsi nahi da ea zein arrazoirengatik egiten duten hautua hurrenkera baten edo bertzearen alde.

\subsection{Ikergalderak}

Ikerketa honetan planteatu ditugun galderak hauek dira:

1. Lehen Hezkuntzako irakasle-gaien laginak zer elementu-ordena du nahiago: atzerakarga handia dakarren hurrenkera, ala nahiago du atzerakarga txikiagoa dakarren elementuen ordena? Zenbatekoa da gai horretaz erakusten duen joera?

2. Irakasle-gaien lagin horrek zer arrazoi adierazten du bere hautua justifikatzeko? 
Ikerketako hipotesi gisa planteaturik, berriz, honela formulatuko genituzke:

H-1. Lehen Hezkuntzako irakasle-gaien laginak nahiago izanen ditu erranaldiko elementuak ordenatu atzerakarga handiagoarekin. Hipotesi hori onetsi edo gaitzetsi nahi dugu. Gainera, datuak bildu nahi ditugu, ikusteko nolako indarra duen joera horrek.

H-2. Analizaturiko laginak irizpide gramatikal formalak aipatuko ditu bere hobespena justifikatzeko. Jakin nahi dugu zer arrazoi aipatzen duten erantzuleek justifikatzeko eurek adieraziriko hobespena, erranaldiko elementuen hurrenkera bat edo bertzea nahiago izateko.

\subsection{Datuak biltzea eta haien trataera}

\subsubsection{Analizaturiko erranaldiak}

Ikersaio honetan 25 erranaldi pare arakatu dira, haien elementuak ordenaturik bi modu desberdinetan. Erranaldi horien bi bertsioak 1 koadroan ikus daitezke. Erranaldiak ez dira oso laburrak (bat izan ezik) baina ez hagitz luzeak ere: salbuespeneko kasua kenduta, laburrenak 21 silaba ditu eta luzeenak 60. Azterturiko erranaldien luzera, batez bertze, 40 silabakoa da. Erranaldi bat bakarra da aditz bakarrekoa, eta gainerakoetan mendeko perpausak ageri dira, mota desberdinetakoak: badira konpletiboak, denborazkoak, erlatibozkoak, moduzkoak, baldintzazkoak, kausazkoak, zehargalderak, denborazko-ondoriozkoak, kontzesiboak...

Erranaldi horiek pareka jarrita, lagineko ikasleei aurkezten zaizkie eta eskatzen zaie aukera dezatela zein den hobekien antolatua. Erranaldien bertsio bakoitzari atzerakarga desberdin bat egozten diogu, elementuak nola ordenatuak dituen ${ }^{5}$. Oro har, gure prozeduran aditzen posizioek markatzen dute zein den atzerakarga handieneko bertsioa eta zein txikienekoa.

Hauxe izan da gure prozedura, datuak tratatzeko: erranaldi pare batean hobesten bada hain zuzen aditza lehenago jarria duen aukera, orduan 0 balioa ematen diogu jokabide horri $(0=\mathrm{ez}$ da atzerakarga handiko ordena hobesten); aditza atzerago jarria duen ordenari, berriz, 1 balioa ematen diogu ( 1 = atzerakarga handiko ordena hobesten da). Nolanahi ere, prozedurazko zalantzak uxatu nahirik, 1. koadroan ikus daiteke erranaldi pare bakoi-

5 Salbuespen batekin: 1. koadroko 1. erranaldia oso laburra da eta maila praktikoan ez da garbiro bereizten atzerakarga handiaren eta txikiaren arteko aldea (izan ere erranaldi luzeetan sumatzen baita errazenik atzerakargaren efektu oztopagarria). Horregatik, kasu horretan ez ditugu bi ordenak desberdintzen atzerakargaren parametroari dagokionez. 
tzetik zein den atzerakarga txikienekotzat jotzen duguna gure prozeduran: izartxo batez markatua da.

Inkestatuek bertze bi aukera ere badituzte, emaniko ordenetatik bat hautatzeko posibilitateaz gainera: bi hurrenkerak ontzat ematea (aukera horri gure kodetzeko prozeduran 2 balioa eman diogu), eta bi aukerak txartzat ematea (gure kodetzean, 3 balioa jarri diogu).

Analizaturiko erranaldi-pareak ikerlan honetarako hautatzeko, irizpide hauek eduki ditugu gogoan:

1. erranaldiak, bi hurrenkeretan jarrita ere, gramatikalki zuzenak eta onartzekoak izan daitezela (kontuan hartuta euskaraz perpauseko elementuen ordena nahiko libretzat jotzen dela; ikus Euskaltzaindia, 1987, 1991; Laka, 1996);

2. erranaldiek aukera eman dezatela beren elementuen ordenak kontrastatzeko zerekin-eta eredu idealista-idiosinkratikoaren arabera nagusi zen irizpideren batekin; gogora dezagun goian lau irizpide nagusi aipatzen genituela: a) erranaldietan galdegaia izaten da informazio-elementurik garrantzitsuena eta hura jartzen da aditzaren aitzin-aitzinean; b) aditza erranaldiaren amaieran jarri ohi/behar da; c) menpeko perpausak aditz nagusiaren aurretik jarri behar dira; d) menpekotasuna adierazteko morfemak edo elementuak mendeko perpausaren amaieran jarri behar dira.

Aurreko paragrafoan aipaturiko lau ezaugarri horietatik lehenbizikoa ez dugu analizatzen lan honetan. Saio honetan galdegaiaren kontua ez da aztertzen. Erranaldien antolamenduaz galdetzean ez da testuingururik zehazten ia batere. Oro har, pentsa daiteke informazio guzia berria dela eta dena dela berdin inportantea. Nolanahi ere, argudiatuko balitz pareetako bi erranaldiek batzuetan ez dutela zehazki erranahi bera, galdegaia zein den ez dakigulakoz, erranen genuke ezen galdegaiaren kezka lukeen inkestatuak beti hauta lezakeela berdintzat eta ontzat ematea pare bakoitzeko bi antolamenduak, eta arrazoi gisa azaldu lezakeela ezen galdegaia zein den, erranaldi biak zuzenak eta egokiak izan litezkeela.

Gure ustez, beraz, azterturiko erranaldiak nahiko ongi uler daitezke beregain hartuta; testuinguruaren euskarria ez da nahitaezkoa, eskatzen den ariketa modu erranahitsuan egiteko; erranaldiak nahiko «beregainak» dira eta ez da ezinbertzekoa haiek aurkeztea testu-zati luzeagoetan sartuta.

Ondoan datorren 1. koadroan ikus daitezke azterturiko erranaldi guztiak, eta zein jotzen dugun atzerakarga txikiagokotzat (izartxoa duena). 
1. koadroa

Azterturiko erranaldiak (erranaldi pare bakoitzean, izartxoa duen erranaldia jotzen da atzerakarga txikiagokotzat $(*)$

1.a) Ona da hori jakitea (*)

1.b) Ona da jakitea hori $(*)$

2.a) Ona da norberak jakitea bazkaria prestatzen eta etxeko lanak egiten. (*)

2.b) Ona da norberak bazkaria prestatzen eta etxeko lanak egiten jakitea.

3.a) Italiarrak pozik daude, ikusitakoan Frantzia nola itzuli den etxera txapelketatik. $(*)$

3.b) Italiarrak pozik daude, Frantzia nola itzuli den etxera txapelketatik ikusitakoan.

4.a) Deialdi hau zuzenduta dago aurreko urteetan Erasmus programan ibili diren ikasleei. $(*)$

4.b) Deialdi hau aurreko urteetan Erasmus programan ibili diren ikasleei zuzenduta dago.

5.a) Nik nahi dut bokata bat patata-tortilla eta kas bat laranja. (*)

5.b) Nik patata-tortillazko bokata bat eta laranjazko kas bat nahi dut.

6.a) Denek egin behar dituzte ariketa batzuk balio dutenak gai horren inguruan oinarrizko trebakuntza jasotzeko. (*)

6.b) Denek egin behar dituzte gai horren inguruan oinarrizko trebakuntza jasotzeko balio duten ariketa batzuk.

7.a) Konpetentzien bidezko planteamenduak eskatzen du etengabe mugitzea konpetentzia orokorretatik berezietara eta haietatik operatiboetara. $(*)$

7.b) Konpetentzien bidezko planteamenduak, konpetentzia orokorretatik berezietara eta haietatik operatiboetara etengabe mugitzea eskatzen du.

8.a) Ezin zara irten futbol zelaira pentsamenduarekin aurrean duzun taldea zurea baino hobea dela. (*)

8.b) Ezin zara irten futbol zelaira aurrean duzun taldea zurea baino hobea delako pentsamenduarekin.

9.a) Madrileko elkarte batzuek prentsa ohar bat bidali zuten atzo, adierazi nahian Euskal Herrian Korrika egiten ari diren euskaltzaleekiko elkartasuna. (*)

9.b) Madrileko elkarte batzuek prentsa ohar bat bidali zuten atzo, Euskal Herrian Korrika egiten ari diren euskaltzaleekiko elkartasuna adierazi nahian.

10.a) Ezin da aldaketa sakonik proposatu sistema guztian, kontuan hartu gabe hezkuntza instituzioko eragile garrantzitsuena (irakaslea). ${ }^{*}$ )

10.b) Ezin da aldaketa sakonik proposatu sistema guztian, hezkuntza instituzioko eragile garrantzitsuena (irakaslea) kontuan hartu gabe. 
11.a) Langileek segur aski grebara joko dute, jakin ondoren beren enpresak laster atzerrira31 joateko asmoa duela. (*)

11.b) Langileek segur aski grebara joko dute, beren enpresak laster atzerrira joateko asmoa duela jakin ondoren.

12.a) Zure hauteskundeen aurrerapenari buruzko iritzia jakin nahi dut.

12.b) Zure iritzia jakin nahi dut hauteskundeen aurrerapenari buruz. (*)

13.a) Beste alde batetik, Adituen Batzordeari ez zaio ahaztu azpimarratzea Estatu mailako hedabideek ez dutela espainiar Estatuko hizkuntza aniztasuna islatzen. $(*)$

13.b) Beste alde batetik, Adituen Batzordeari ez zaio ahaztu Estatu mailako hedabideek ez dutela espainiar Estatuko hizkuntza aniztasuna islatzen azpimarratzea.

14.a) Esaldi bat oker ulertzeko arriskua baldin badago, obligazioa dago arrisku hori minimizatzeko eta horretarako behar diren tresna guztiak erabiltzeko. (*)

14.b) Esaldi bat oker ulertzeko arriskua baldin badago, arrisku hori minimizatzeko eta horretarako behar diren tresna guztiak erabiltzeko obligazioa dago.

15.a) Esperantza dut gaurko negar guztiak egunen batean irri bihurtuko direla. (*) 15.b) Gaurko negar guztiak egunen batean irri bihurtuko direlako esperantza dut.

16.a) Gaur hartu dut mezua datorren ikasturtean gelan beste laguntzaile bat izango dudala. (*)

16.b) Datorren ikasturtean gelan beste laguntzaile bat izango dudalako mezua gaur hartu dut.

17.a) «Aurreiritzi» hitza aipatu dugu uste dugulako hizkuntza gutxiagotuak deitu beharko litzaiekeela hizkuntza txikiak edo minoritarioak deitu ordez. (*)

17.b) «Aurreiritzi» hitza aipatu dugu, hizkuntza txikiak edo minoritarioak deitu ordez hizkuntza gutxiagotuak deitu beharko litzaiekeela uste dugulako.

18.a) Ikastetxeetan ere, gela nola antolatuta dagoen ikusteak ideia ematen digu nolako estilokoa den irakaslea edo bertan garatuko den jarduna. $(*)$

18.b) Ikastetxeetan ere, gela nola antolatuta dagoen ikusteak irakaslea edo bertan garatuko den jarduna nolako estilokoa den ideia ematen digu.

19.a) Ezinegona ekarri zidan jakiteak gure laguna berriz lanean hasia zela ondo sendatu gabe. $(*)$

19.b) Ezinegona ekarri zidan gure laguna ondo sendatu gabe berriz lanean hasia zela jakiteak.

20.a) Bittor Hidalgok artikulu bat argitaratu du Senez aldizkarian gaitzat hartuta zer kokaleku duen galdegaiak perpausean. (*)

20.b) Bittor Hidalgok artikulu bat argitaratu du Senez aldizkarian galdegaiak perpausean zer kokaleku duen gaitzat hartuta. 
21.a) Ona da hasieratik jabetzea nork agintzen duen eta nor den morroi. (*)

21.b) Ona da nork agintzen duen eta nor den morroi hasieratik jabetzea.

22.a)Are gehiago, ikusirik nola lagundu dezakeen Internetek hizkuntza gutxituentzat tokia bilatzen, alor hori bereziki zaintzea pentsatu da. $\left.{ }^{*}\right)$

22.b)Are gehiago, Internetek hizkuntza gutxituentzat tokia bilatzen nola lagundu dezakeen ikusirik, alor hori bereziki zaintzea pentsatu da.

23.a) Ez du batere ahaleginik egin guri laguntza bidaltzeko, badakien arren oso jende gutxi garela eta lan handiegia dugula. $(*)$

23.b) Ez du batere ahaleginik egin guri laguntza bidaltzeko, oso jende gutxi garela eta lan handiegia dugula badakien arren.

24.a) Esaldi hori zaila da ulertzen, bai, baina jarriz gero mendeko perpausak nagusiaren aurretik, oraindik zailagoa izango litzateke. $(*)$

24.b) Esaldi hori zaila da ulertzen, bai, baina mendeko perpausak nagusiaren aurretik jarriz gero, oraindik zailagoa izango litzateke.

25.a) Eusko Jaurlaritzako Hezkuntza Sailak atzo aurkeztu zuen ikasliburuak doan ezartzeko erabiliko den formula.

25.b) Eusko Jaurlaritzako Hezkuntza Sailak atzo aurkeztu zuen zer formula erabiliko den ikasliburuak doan ezartzeko. (*)

\subsubsection{Inkestaren zatiak}

Ikerketarako erabiliriko galde-sortak baditu bi zati desberdin: alde batetik, erantzuleei galdetu zaie ea zein ordena duten nahiago, emaniko ordenamendu bietatik; eta bertzetik, jakin nahi dugu zein arrazoi baliatzen den hautespena justifikatzeko ${ }^{6}$.

Lehenengo zatiari erantzuteko, inkestatuek adierazi behar dute ea zein den eurek hobesten duten elementu-hurrenkera, eta badute aukera, gainera, bi hurrenkerak ontzat emateko, eta baita biak gaitzesteko ere, baldin eta biak jotzen badira onartzeko edo ez-onartzeko modukotzat (adibidez, testuinguruaren arabera).

Bigarren zatia egiteko, berriz, sei erantzun estandar eskaintzen zaizkio inkestatuari aukeran (ikus 1. eranskina: hautespena egiteko arrazoiak nola formulatuak ziren); erantzun horiek ez dira kasu guzietan elkarren baztertzaile, hau da, haietatik bat baino gehiago hauta daiteke (adibidez, konbina daitezke erantzun hauek: «1. Beste hurrenkera euskaraz ez delako zuzena»,

\footnotetext{
6 Aztergaiari buruzko erranaldi-sortarekin hasi aitzinean inkestatuei galdetu zaie bertze aldagai batzuez ere, hala norbanakoaren eta talde osoaren profil sozio-psikolinguistikoa zedarritzeko. Geroago azalduko dugu zein diren aldagai horiek.
} 
eta «5. Euskaraz aditza atzean jartzen delako»). Ondoko 6 paragrafoetan azalduko ditugu, labur, aukeran eskaintzen ziren erantzun «estandar» posible horiek:

1. lehen erantzun batek adierazten du irizpide gramatikal «purua» edo «gordina»: erantzuleak hautatzen du hurrenkera bat, zergatik-eta bertzea ez delakoz zuzena, hots, bertzea gramatikalki okerra dela uste duelakoz (honela formulatua da, zehazki: «Bestea (hautatu ez dudana) euskaraz ez delako zuzena»);

2. bigarren erantzunak erakusten du «irizpide gramatikal erlatiboa», edo, bertzela erranik, kanonarekin erlazionaturiko hobespena da, kanona ulerturik hizkuntzaren erabilera ereduzko gisa ${ }^{7}$ : hurrenkera bat bertzea baino «hobea» da, «euskara hobea» da, nahiz eta bertzea ere onar daitekeen edo baliozkoa den (formulazio zehatza: «Hautatu dudana euskaraz jatorragoa delako, euskara hobea delako»);

3. hirugarren erantzun batek pragmatikazko hobespen-irizpidea baliatzen du: bi hurrenkerak zuzenak dira eta biek balio dute, baina haietako bat bertzea baino hobeto irakurtzen da, errazago ulertzen da, hots, hobea da pragmatikaren ikuspuntutik (honela jarria: «Hautatu dudana errazago irakurtzen/ulertzen delako»);

4. laugarren aukera batek kanale-desberdintasunari egiten dio erreferentzia, ohartuta edo ohartu gabe kontsideratuz ezen kode idatzia zorrotzagoa/meharragoa dela edo hobeto mugatua eta definitua dela, ahozkoa baino: ordenamendu bat bertzea baino hobea da kode idatzian, nahiz eta ahozkoan biak ere onartzeko modukoak kontsideratu (formulazioa honela: «Hautatu dudana idatzian hobeto dagoelako (ahozkoan bestea ere onartuko nuke)»;

5. bosgarren aukerak irizpide formal posiziozko bat adierazten du, baieztapen honetan bildu daitekeena: «Euskaraz aditza atzean jartzen da» (formulazio zehatz honen bidez adierazia: «Euskaraz aditza atzean jartzen delako»);

6. orain artean azalduriko bortz aukera horiez gainera, bertze hautabide bat ere eskaintzen zaio inkestatuari, hark nahi badu ere bertze arrazoiren bat erran, lehen aipatu diren erantzun horietaz haratago; kasu honetan, inkestatuari eskatzen zaio adieraz dezala zer arrazoi berezirengatik egiten duen hautespena (honela adierazia: «Beste arrazoi batengatik - esan mesedez arrazoia-»).

\footnotetext{
7 Kanonaz ikus http://dle.rae.es/?id=7A4XonT (kontsulta: 2017-03-17) eta http://www euskaltzaindia.eus/index.php?option=com_xslt\&lang=eu\&layout=lth_detail\&view=front page \&Itemid=474\&search=kanon http://www.euskaltzaindia.eus/index.php?option=com xslt\&lang=eu\&layout=lth_detail\&view=frontpage \&Itemid=474\&search=kanon) (kontsulta: 2017-03-17).
} 


\subsection{Inkestatuen lagina}

Lan honen helburua da informazioa aurkitzea ea nolako jarrera erakusten duten unibertsitateko ikasle batzuek hitzen ordenari buruz euskarazko erranaldi sorta batean. Zehatzago errateko, ikusi nahi da ea etorkizunean Lehen Hezkuntzako irakasle izanen direnen lagin batek nolako jokabidea erakusten duen gai horri buruz. Horretarako, Lehen Hezkuntzako Gradua egiten ari diren 172 ikaslek egin dute ikerketa honetako ariketa. Inkestatuak unibertsitateko lehen mailan ari ziren, UPV/EHUko 3 campusetako Irakasle Eskoletan (Bilbo, Donostia eta Gasteiz), 2011-2012 ikasturtean. Kopuru hori \%30 da, baldintza horiek betetzen dituzten ikasle-unibertso guzitik (571 ikasle ari ziren urte horretan UPV/EHUn aipaturiko gradua egiten lehen mailan).

Datuak biltzeko, prozedura hauxe baliatu zen: ikasturtearen lehen lauhilabetekoan inkestagileak agertu ziren eskola-egun arrunt batzuetan, aitzinetik gaztigatu gabe, irakasle-gai horien ohiko ikasgeletan ${ }^{8}$ (hango irakaslearen adostasunarekin); horrela bermatu nahi ziren ahalik eta baldintzarik «ohikoenak» edo «naturalenak» proba egiteko orduan, hau da, ziurtatu nahi zen ariketa hori egin beharrak ez zuela eragin nabaririk izanen ikasleen presentzian edo absentzian, eta beraz laginaren osaketan. Eta horrela, lanaren aurkezpena eginda ikasleei eskatu zitzaien aurkezturiko ariketa bururatzeko, betiere modu boluntarioan. Zeregina banatu eta azaldu ondotik, berrogei minutu inguru izan zuten ikasleek lana egiteko (bortz ikasle, laginaren \%2`9, ez ziren iritsi ariketa amaitzera: 16. eta 19. itemen artean gelditu ziren). Bertzalde, ariketa egiteko beharrezkoak ziren antolamendu-zertzeladak ikasleen ohiko unibertsitate-irakasleen lankidetzaren bidez prestatu ziren ${ }^{9}$.

\subsubsection{Inkestatuen laginaren ezaugarri batzuk}

Atal honetan azaltzen ditugu iker-ariketa bete duten ikasleen ezaugarri nagusi batzuk, horrela talde guziaren izaera hein batean zehazteko. Ondoan datozen datu horiek bildu ditugu:

a) ikasleen herriaz (inguruneko euskaldun kopuruaz): honen bidez informazioa bildu nahi izan dugu laginako ikasleen ohiko hizkuntzainguruneaz, eta gero ikasle guzien batez bertzekoak atera ditugu, talde guzia bat hartuta ezaugarri horri dagokionez. Aldagai honi

\footnotetext{
8 Ariketa egin zutenei erreferentzia egiteko, bai irakasle-gai eta bai ikasle edo inkestatu hitzak erabiltzen ditugu, balio berarekin.

${ }^{9}$ Gure esker ona adierazi nahi diegu irakasle hauei: Kepa Larrea, Ander Olalde, Ainhoa Ezeiza, Urtza Garay eta Aintzane Etxebarria. Haien laguntzarik gabe ezin izanen genuen lana antolatu eta bururatu.
} 
buruz, datu orokor hauek nabarmentzen ditugu, Euskal Herriko Inkesta Soziolinguistikoetan egin ohi den lau gune soziolinguistikoen banaketa baliatuta ${ }^{10}:$ 1) gune soziolinguistikoen arabera, hauek dira laginako ikasleen kopuruak: 1 . gunean bizi da ikasleen \%6,6; 2 . gunean, \%61,6; 3. gunean, \%26,2; eta 4. gunean, \%4,7 (ikusten denez, ikasleen erdiak baino gehiago 2. gune herrietakoak dira); 2) ikasle guzien batez bertzeko ehunekoa, haien inguruneko hiztun euskaldunei dagokienez, hauxe da: \%42,3 (hots, laginaren batez bertzeko ikasleak, bere balizko batez bertzeko herrian, biztanleen \%42,3 izanen lituzke euskaldunak);

b) adinaz: ariketa egin zuten ikasleen batez bertzeko adina 18,7 urte izan da;

c) euskara etxean ikasi duten edo ez galdeturik, baiezko erantzuna izan da $\% 52,3 \mathrm{an}^{11}$; ezezko erantzuna eman du \%47,1ek (beraz, erdiak baino gehixeagok ikasi du euskara etxean);

d) galdeturik ea zer hezkuntza-eredutan egin dituzten ikasketak, hauek izan dira emaitzak: D ereduan, \%86k; B ereduan, \%11,6k; A ereduan, \%1,2k (ikusten denez, D ereduan ikasi dutenen ehunekoa oso handia da, eta A eredukorik ia ez da);

e) galdetu zaie, baita, ea etxean euskara erabiltzen duten edo ez, eta emaitza izan da \%50ek bai erabiltzen duela, eta \%48,8k ezetz (ia erdi eta erdi zehazki);

f) etxean euskalkia erabiltzen duten galdeturik, hauxe izan da erantzuna: \%48,3k dio baietz, eta \%50ek ezetz (berriz ere, ia zehazki erdi eta erdi, baina ordena desberdinean);

g) gramatika ikasteko zer iturri baliatzen duten galdeturik, erantzuna izan da ikasle gehienek ikasgelan jasoriko azalpenak dituztela erreferentzia nagusia ${ }^{12}$ : \%97,1ek; bertze erantzun batzuk hauek dira: gramatika-liburu eta material inprimatutik, \%45,3k; internetetik, $\% 33,7 \mathrm{k}$; eta ikastaro bereziak jasotzen ditu ikasleen $\% 12,8 \mathrm{k}$.

10 Euskal Herriko Inkesta Soziolinguistikoetan erabili ohi den 4 guneko banaketa: 1. gunea, \%0-20; 2. gunea, \%20-50; 3. gunea, \%50-80; 4. gunea: \%80-100. Bertzalde, ikasleen ingurune linguistikoari dagozkion datuak biltzeko, iturri hauek baliatu ditugu: 1) Soziolinguistikako Klusterrak UEMArentzat eginiko herriz herriko laburpena; baliatu dugun parametroa euskaldunen kopurua izan da, ehunekoetan, baina baliagarri izan liteke orobat txosten horretan ageri den bertze indize bat ere: euskararen indizea (ikus IURREBASOSOZIOLINGUISTIKA KLUSTERRA, 2014); 2) Nafarroako datuak, berriz, Euskarabidea zerbitzuak helarazi dizkigu (eskerrak eman nahi dizkiegu gure eskariari jarririko arretarengatik).

11 Pertsona batek erraten badu euskara etxean ikasi duela, kontsidera daiteke euskara dela bere lehen hizkuntza $(1 \mathrm{H})$, dela bakarra izanik edo dela bertze hizkuntzaren batekin (lan honen testuinguruan normalean gaztelania izanen dena). keen.

12 Galdera horretan erantzun batzuk eskaintzen ziren, eta bat baino gehiago hauta zite- 
Aldagai horien balizko eragina aztertzea bertze lan baterako uzten dugu, baina nabarmentzekoa iduritzen zaigu laginaren erditsuak ikasi duela euskara etxean, eta erditsuak egiten duela euskalkian.

\subsection{Emaitzak}

Lehen erran dugun bezala, ikersaio honen bidez bi datu mota erdietsi dira: alde batetik, emaniko erranaldi pareetan ea zein hurrenkera hobesten diren, eta bertzetik zer arrazoi argudiatzen den eginiko hautua justifikatzeko. Banaka aipatuko ditugu bi datu-mota horiek, eta bakoitzari dagokion iruzkina.

\subsubsection{Hurrenkera desberdinei buruzko iritziak}

Hurrenkeren hobespenari buruz bilduriko emaitzak 2. koadroan erakusten dira. Koadro horrek 4 zutabe ditu: lehenbizikoan erranaldiak eta beren bi bertsioak ageri dira, izar batez markaturik zein den atzerakarga txikiagokoa; bigarren zutabean erakusten da, ehunekoetan, zenbat erantzulek hobesten duen atzerakarga handiko hurrenkera; hirugarrenean, berriz, agertzen da zenbat erantzulek nahiago duen atzerakarga txikiko hitz-ordena; eta azkenik, laugarrenak biltzen ditu, elkarri batuta, datu hauek: esplizituki atzerakarga txikiko hurrenkera hobetsi dutenak gehi bi ordenamenduak berdintzat jo dituztenak.

\section{2. koadroa}

\section{Azterturiko erranaldiak eta beren emaitzak (\%)}

\begin{tabular}{l|c|c|c}
\hline $\begin{array}{c}\text { ERRANALDIAK ETA ITEMAK } \\
\text { (erranaldi pare bakoitzean, izartxoa duen erranaldia } \\
\text { jotzen da atzerakarga txikiagokotzat: }(*)\end{array}$ & $\begin{array}{c}\text { Atzerakarga } \\
\text { handia } \\
\text { zenbatek } \\
\text { hobetsi } \\
(1 \text { baliokoak) }\end{array}$ & $\begin{array}{c}\text { Atzerakarga } \\
\text { txikia } \\
\text { zenbatek } \\
\text { hobetsi } \\
\text { esplizituki } \\
(0 \text { balioak })\end{array}$ & $\begin{array}{c}\text { Atzerakarga } \\
\text { txikia gehi } \\
\text { biak berdin } \\
\text { ontzat eman } \\
(0 \text { baliokoak gehi } \\
2 \text { baliokoak })\end{array}$ \\
\hline $\begin{array}{l}\text { 1.a) Ona da hori jakitea (*) } \\
\text { 1.b) Ona da jakitea hori (*) }\end{array}$ & 91,9 & 1,7 & 2,3 \\
\hline $\begin{array}{l}\text { 2.a) Ona da norberak jakitea bazkaria presta- } \\
\text { tzen eta etxeko lanak egiten. }(*)\end{array}$ & 83,7 & 4,1 & 12,2 \\
$\begin{array}{l}\text { 2.b) Ona da norberak bazkaria prestatzen eta } \\
\text { etxeko lanak egiten jakitea. }\end{array}$ & & & \\
\hline $\begin{array}{l}\text { 3.a) Italiarrak pozik daude, ikusitakoan Fran- } \\
\text { tzia nola itzuli den etxera txapelketatik. }(*)\end{array}$ & 80,8 & 4,7 & 7 \\
$\begin{array}{l}\text { 3.b) Italiarrak pozik daude, Frantzia nola itzuli } \\
\text { den etxera txapelketatik ikusitakoan. }\end{array}$ & & & \\
\hline
\end{tabular}




\begin{tabular}{|c|c|c|c|}
\hline $\begin{array}{c}\text { ERRANALDIAK ETA ITEMAK } \\
\text { (erranaldi pare bakoitzean, izartxoa duen erranaldia } \\
\text { jotzen da atzerakarga txikiagokotzat: }\left(^{*}\right)\end{array}$ & $\begin{array}{l}\text { Atzerakarga } \\
\text { handia } \\
\text { zenbatek } \\
\text { hobetsi } \\
\text { (1 baliokoak) }\end{array}$ & $\begin{array}{l}\text { Atzerakarga } \\
\text { txikia } \\
\text { zenbatek } \\
\text { hobetsi } \\
\text { esplizituki } \\
\text { (0 balioak) }\end{array}$ & $\begin{array}{l}\text { Atzerakarga } \\
\text { txikia gehi } \\
\text { biak berdin } \\
\text { ontzat eman } \\
\text { (0 baliokoak gehi } \\
2 \text { baliokoak) }\end{array}$ \\
\hline $\begin{array}{l}\text { 4.a) Deialdi hau zuzenduta dago aurreko ur- } \\
\text { teetan Erasmus programan ibili diren ikas- } \\
\text { leei. }\left(^{*}\right) \\
\text { 4.b) Deialdi hau aurreko urteetan Erasmus pro- } \\
\text { graman ibili diren ikasleei zuzenduta dago. }\end{array}$ & 93,0 & 1,2 & 6,4 \\
\hline $\begin{array}{l}\text { 5.a) Nik nahi dut bokata bat patata-tortilla eta } \\
\text { kas bat laranja. }(*) \\
\text { 5.b) Nik patata-tortillazko bokata bat eta laran- } \\
\text { jazko kas bat nahi dut. }\end{array}$ & 82,0 & 5,2 & 6,4 \\
\hline $\begin{array}{l}\text { 6.a) Denek egin behar dituzte ariketa batzuk } \\
\text { balio dutenak gai horren inguruan oinarrizko } \\
\text { trebakuntza jasotzeko. }(*) \\
\text { 6.b) Denek egin behar dituzte gai horren ingu- } \\
\text { ruan oinarrizko trebakuntza jasotzeko balio } \\
\text { duten ariketa batzuk. }\end{array}$ & 92,4 & 2,3 & 5,2 \\
\hline $\begin{array}{l}\text { 7.a) Konpetentzien bidezko planteamenduak } \\
\text { eskatzen du etengabe mugitzea konpetentzia } \\
\text { orokorretatik berezietara eta haietatik operati- } \\
\text { boetara. }(*) \\
\text { 7.b) Konpetentzien bidezko planteamenduak, } \\
\text { konpetentzia orokorretatik berezietara eta haie- } \\
\text { tatik operatiboetara etengabe mugitzea eska- } \\
\text { tzen du. }\end{array}$ & 93,0 & 0 & 7 \\
\hline $\begin{array}{l}\text { 8.a) Ezin zara irten futbol zelaira pentsamen- } \\
\text { duarekin aurrean duzun taldea zurea baino ho- } \\
\text { bea dela. }(*) \\
\text { 8.b) Ezin zara irten futbol zelaira aurrean duzun } \\
\text { taldea zurea baino hobea delako pentsamen- } \\
\text { duarekin. }\end{array}$ & 83,1 & 2,3 & 3,5 \\
\hline $\begin{array}{l}\text { 9.a) Madrileko elkarte batzuek prentsa ohar bat } \\
\text { bidali zuten atzo, adierazi nahian Euskal He- } \\
\text { rrian Korrika egiten ari diren euskaltzaleekiko } \\
\text { elkartasuna. }(*) \\
\text { 9.b) Madrileko elkarte batzuek prentsa ohar bat } \\
\text { bidali zuten atzo, Euskal Herrian Korrika egiten } \\
\text { ari diren euskaltzaleekiko elkartasuna adierazi } \\
\text { nahian. }\end{array}$ & 89,0 & 1,2 & 9,9 \\
\hline
\end{tabular}




\begin{tabular}{|c|c|c|c|}
\hline $\begin{array}{l}\text { ERRANALDIAK ETA ITEMAK } \\
\text { (erranaldi pare bakoitzean, izartxoa duen erranaldia } \\
\text { jotzen da atzerakarga txikiagokotzat: }\left(^{*}\right)\end{array}$ & $\begin{array}{l}\text { Atzerakarga } \\
\text { handia } \\
\text { zenbatek } \\
\text { hobetsi } \\
\text { (1 baliokoak) }\end{array}$ & $\begin{array}{l}\text { Atzerakarga } \\
\text { txikia } \\
\text { zenbatek } \\
\text { hobetsi } \\
\text { esplizituki } \\
\text { (0 balioak) }\end{array}$ & $\begin{array}{l}\text { Atzerakarga } \\
\text { txikia gehi } \\
\text { biak berdin } \\
\text { ontzat eman } \\
\text { (0 baliokoak gehi } \\
2 \text { baliokoak) }\end{array}$ \\
\hline $\begin{array}{l}\text { 10a) Ezin da aldaketa sakonik proposatu sistema } \\
\text { guztian, kontuan hartu gabe hezkuntza institu- } \\
\text { zioko eragile garrantzitsuena (irakaslea). }(*) \\
\text { 10b)Ezin da aldaketa sakonik proposatu sistema } \\
\text { guztian, hezkuntza instituzioko eragile garran- } \\
\text { tzitsuena (irakaslea) kontuan hartu gabe. }\end{array}$ & 85,5 & 2,3 & 12,8 \\
\hline $\begin{array}{l}\text { 11.a) Langileek segur aski grebara joko dute, } \\
\text { jakin ondoren beren enpresak laster atzerrira31 } \\
\text { joateko asmoa duela. }(*) \\
\text { 11.b) Langileek segur aski grebara joko dute, } \\
\text { beren enpresak laster atzerrira joateko asmoa } \\
\text { duela jakin ondoren. }\end{array}$ & 89,0 & 4,1 & 10,5 \\
\hline $\begin{array}{l}\text { 12.a) Zure hauteskundeen aurrerapenari bu- } \\
\text { ruzko iritzia jakin nahi dut. } \\
\text { 12.b) Zure iritzia jakin nahi dut hauteskun- } \\
\left.\text { deen aurrerapenari buruz. }{ }^{*}\right)\end{array}$ & 35,5 & 29,1 & 59,9 \\
\hline $\begin{array}{l}\text { 13.a) Beste alde batetik, Adituen Batzordeari ez } \\
\text { zaio ahaztu azpimarratzea Estatu mailako he- } \\
\text { dabideek ez dutela espainiar Estatuko hizkuntza } \\
\text { aniztasuna islatzen. (*) } \\
\text { 13.b) Beste alde batetik, Adituen Batzordeari ez } \\
\text { zaio ahaztu Estatu mailako hedabideek ez du- } \\
\text { tela espainiar Estatuko hizkuntza aniztasuna is- } \\
\text { latzen azpimarratzea. }\end{array}$ & 66,9 & 10,5 & 26,7 \\
\hline $\begin{array}{l}\text { 14.a) Esaldi bat oker ulertzeko arriskua baldin } \\
\text { badago, obligazioa dago arrisku hori minimiza- } \\
\text { tzeko eta horretarako behar diren tresna guztiak } \\
\text { erabiltzeko. }\left(^{*}\right) \\
\text { 14.b) Esaldi bat oker ulertzeko arriskua baldin } \\
\text { badago, arrisku hori minimizatzeko eta horre- } \\
\text { tarako behar diren tresna guztiak erabiltzeko } \\
\text { obligazioa dago. }\end{array}$ & 79,7 & 4,1 & 19,2 \\
\hline $\begin{array}{l}\text { 15.a) Esperantza dut gaurko negar guztiak } \\
\text { egunen batean irri bihurtuko direla. (*) } \\
\text { 15.b) Gaurko negar guztiak egunen batean irri } \\
\text { bihurtuko direlako esperantza dut. }\end{array}$ & 75,0 & 11 & 20,3 \\
\hline
\end{tabular}




\begin{tabular}{|c|c|c|c|}
\hline $\begin{array}{l}\text { ERRANALDIAK ETA ITEMAK } \\
\text { (erranaldi pare bakoitzean, izartxoa duen erranaldia } \\
\text { jotzen da atzerakarga txikiagokotzat: }\left({ }^{*}\right)\end{array}$ & $\begin{array}{l}\text { Atzerakarga } \\
\text { handia } \\
\text { zenbatek } \\
\text { hobetsi } \\
\text { (1 baliokoak) }\end{array}$ & $\begin{array}{l}\text { Atzerakarga } \\
\text { txikia } \\
\text { zenbatek } \\
\text { hobetsi } \\
\text { esplizituki } \\
\text { (0 balioak) }\end{array}$ & $\begin{array}{l}\text { Atzerakarga } \\
\text { txikia gehi } \\
\text { biak berdin } \\
\text { ontzat eman } \\
\text { (0 baliokoak gehi } \\
2 \text { baliokoak) }\end{array}$ \\
\hline $\begin{array}{l}\text { 16.a) Gaur hartu dut mezua datorren ikas- } \\
\text { turtean gelan beste laguntzaile bat izango du- } \\
\text { dala. (*) } \\
\text { 16.b) Datorren ikasturtean gelan beste lagun- } \\
\text { tzaile bat izango dudalako mezua gaur hartu } \\
\text { dut. }\end{array}$ & 73,3 & 7,6 & 14,5 \\
\hline $\begin{array}{l}\text { 17.a) «Aurreiritzi» hitza aipatu dugu uste du- } \\
\text { gulako hizkuntza gutxiagotuak deitu beharko } \\
\text { litzaiekeela hizkuntza txikiak edo minoritarioak } \\
\text { deitu ordez. }(*) \\
\text { 17.b) «Aurreiritzi» hitza aipatu dugu, hizkun- } \\
\text { tza txikiak edo minoritarioak deitu ordez hiz- } \\
\text { kuntza gutxiagotuak deitu beharko litzaiekeela } \\
\text { uste dugulako. }\end{array}$ & 76,7 & 8,1 & 22,1 \\
\hline $\begin{array}{l}\text { 18.a) Ikastetxeetan ere, gela nola antolatuta da- } \\
\text { goen ikusteak ideia ematen digu nolako estilo- } \\
\text { koa den irakaslea edo bertan garatuko den jar- } \\
\text { duna. (*) } \\
\text { 18.b) Ikastetxeetan ere, gela nola antolatuta da- } \\
\text { goen ikusteak irakaslea edo bertan garatuko } \\
\text { den jarduna nolako estilokoa den ideia ema- } \\
\text { ten digu. }\end{array}$ & 72,7 & 9,3 & 23,8 \\
\hline $\begin{array}{l}\text { 19.a) Ezinegona ekarri zidan jakiteak gure } \\
\text { laguna berriz lanean hasia zela ondo sendatu } \\
\text { gabe. }(*) \\
\text { 19.b) Ezinegona ekarri zidan gure laguna } \\
\text { ondo sendatu gabe berriz lanean hasia zela ja- } \\
\text { kiteak. }\end{array}$ & 77,3 & 7,0 & 17,4 \\
\hline $\begin{array}{l}\text { 20.a) Bittor Hidalgok artikulu bat argitaratu du } \\
\text { Senez aldizkarian gaitzat hartuta zer kokaleku } \\
\text { duen galdegaiak perpausean. }(*) \\
\text { 20.b) Bittor Hidalgok artikulu bat argitaratu du } \\
\text { Senez aldizkarian galdegaiak perpausean zer ko- } \\
\text { kaleku duen gaitzat hartuta. }\end{array}$ & 82,6 & 7,6 & 14,5 \\
\hline $\begin{array}{l}\text { 21.a) Ona da hasieratik jabetzea nork agin- } \\
\text { tzen duen eta nor den morroi. }(*) \\
\text { 21.b) Ona da nork agintzen duen eta nor den } \\
\text { morroi hasieratik jabetzea. }\end{array}$ & 51,2 & 15,1 & 41,3 \\
\hline
\end{tabular}




\begin{tabular}{|c|c|c|c|}
\hline $\begin{array}{c}\text { ERRANALDIAK ETA ITEMAK } \\
\text { (erranaldi pare bakoitzean, izartxoa duen erranaldia } \\
\text { jotzen da atzerakarga txikiagokotzat: }\left(^{*}\right)\end{array}$ & $\begin{array}{l}\text { Atzerakarga } \\
\text { handia } \\
\text { zenbatek } \\
\text { hobetsi } \\
\text { (1 baliokoak) }\end{array}$ & $\begin{array}{l}\text { Atzerakarga } \\
\text { txikia } \\
\text { zenbatek } \\
\text { hobetsi } \\
\text { esplizituki } \\
\text { (0 balioak) }\end{array}$ & $\begin{array}{l}\text { Atzerakarga } \\
\text { txikia gehi } \\
\text { biak berdin } \\
\text { ontzat eman } \\
\text { (0 baliokoak gehi } \\
2 \text { baliokoak) }\end{array}$ \\
\hline $\begin{array}{l}\text { 22a)Are gehiago, ikusirik nola lagundu deza- } \\
\text { keen Internetek hizkuntza gutxituentzat tokia } \\
\text { bilatzen, alor hori bereziki zaintzea pentsatu } \\
\text { da. }\left({ }^{*}\right) \\
\text { 22b)Are gehiago, Internetek hizkuntza gutxi- } \\
\text { tuentzat tokia bilatzen nola lagundu dezakeen } \\
\text { ikusirik, alor hori bereziki zaintzea pentsatu da. }\end{array}$ & 81,4 & 8,1 & 14,0 \\
\hline $\begin{array}{l}\text { 23.a) Ez du batere ahaleginik egin guri laguntza } \\
\text { bidaltzeko, badakien arren oso jende gutxi ga- } \\
\text { rela eta lan handiegia dugula. (*) } \\
\text { 23.b) Ez du batere ahaleginik egin guri laguntza } \\
\text { bidaltzeko, oso jende gutxi garela eta lan han- } \\
\text { diegia dugula badakien arren. }\end{array}$ & 72,1 & 9,3 & 25,0 \\
\hline $\begin{array}{l}\text { 24.a) Esaldi hori zaila da ulertzen, bai, baina } \\
\text { jarriz gero mendeko perpausak nagusiaren } \\
\text { aurretik, oraindik zailagoa izango litzateke. }\left(^{*}\right) \\
\text { 24.b) Esaldi hori zaila da ulertzen, bai, baina } \\
\text { mendeko perpausak nagusiaren aurretik ja- } \\
\text { rriz gero, oraindik zailagoa izango litzateke. }\end{array}$ & 85,5 & 9,9 & 13,4 \\
\hline $\begin{array}{l}\text { 25.a) Eusko Jaurlaritzako Hezkuntza Sailak } \\
\text { atzo aurkeztu zuen ikasliburuak doan ezar- } \\
\text { tzeko erabiliko den formula. } \\
\text { 25.b) Eusko Jaurlaritzako Hezkuntza Sailak } \\
\text { atzo aurkeztu zuen zer formula erabiliko den } \\
\text { ikasliburuak doan ezartzeko. }\left(^{*}\right)\end{array}$ & 26,7 & 38,4 & 66,3 \\
\hline Batez bertzeko emaitza globalak (\%) & 76,8 & 8,2 & 18,5 \\
\hline
\end{tabular}


Beheko 1. grafikoan ikus daitezke item guztien batez bertzeko datu globalak.

\section{Zein ordenamendu-eredu hobetsi?}

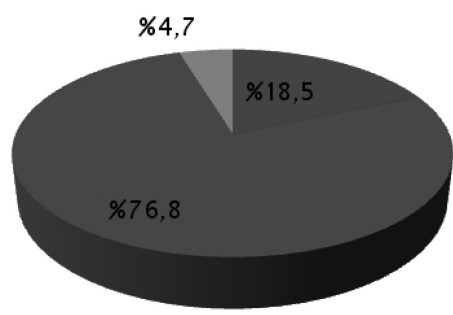

- Atzerakarga txikikoak hobetsi (esplizituki hautatuak + biak berdintzat emanak)

- Atzerakarga handikoak hobetsi

Bertzerik

1. grafikoa

zein ordena hobesten duten ikasleek (\%)

\subsubsection{Zein hurrenkera hobetsi diren: iruzkina}

Datu orokor batzuk aipatuko ditugu bereziki erranahi handikoak idurituta.

a) Batez bertze, erantzunen $\% 76$ ' $8 \mathrm{k}$ adierazten du nahiago duela atzerakarga handiko ordenamendua (erran liteke, beraz, 25 erranaldietatik 19,2tan ageri dela hautu hori; desbideratze tipikoa 3,69 da); $\% 8,2 \mathrm{k}$ nahiago du atzerakarga txikiko hurrenkera (hau da, 25etik 2 item; desbideratze tipikoa 2,82 da); \%10,3k bi aukerak ontzat ematen ditu (hots, 25 aztergaietatik 2,6k eginen luke hautu hori; desbideratze tipikoa da 2,35); azkenik, \%4,7k erakusten du bi formulazioak txartzat ematen dituela (horrek erran nahi luke 25 erranaldietatik 1,2ren baliokideak ez liratekeela zuzenak ez hurrenkera batean jarrita ez bertzean; desbideratze tipikoa 2,2). Azken datu hori dela eta, gogora dezagun gure ikuspuntutik ez dela arrazoirik ezein erranaldi gramatikalki okertzat emateko. Datu hauek batera hartuta koherente datoz bertze bi inkestatan bilduriko emaitzekin, haietan ere atzerakarga handiko formak hobesten baitziren (Maia \& Larrea, 2013; Maia, 2015b);

b) azterturiko item guziek ez dute trataera bera jaso inkestatuen aldetik; atzerakarga handiena bildu duen itemak erantzunen $\% 93$ jaso $\mathrm{du}$, eta atzerakarga txikiena beretu duen erranaldiak erantzunen $\% 26$ hartu du; bertzalde, 25 erranaldi pareetatik 13tan inkestatuen $\% 80 \mathrm{k}$ baino gehiagok nahiago izan du atzerakarga handieneko hurrenkera;

c) ikerketa-ariketan parte hartu duten zuzentzaileen soslaiari buruz, berriz, aipatzekoa iduritzen zaigu orobat pertsona inkestatuen 
$\% 75 \mathrm{ek}$ baino gehiagok nahiago izan dituela item atzera-kargatuenak gutxienean itemen \%72tan; atzerakargarako joera handiena erakutsi duen pertsonak azter-item guzietan erakutsi du jaidura hori, hau da, 25 erranaldietatik 25etan (horrek balio dezake, gainera, erakusteko inkestako item guziek bazutela diskriminatzeko balioa); nabarmentzekoa da halaber ezen atzerakargarako joera txikiena agertu duen pertsonak ere gibelkargarako jaidura erakutsi duela 25 itemetatik 12tan);

\subsubsection{Zergatik hobetsi diren hurrenkera horiek (hautuen arrazoiak)}

Hurrenkera bat edo bertzea hautatzeko aipatu diren arrazoien artean, datu hauek nabarmentzen ditugu (ikus bitez behean datozen 2. grafikoa eta 3. koadroa):

1. orotara, 172 inkestatuek adierazi dituzten arrazoien kopuru absolutua 5.762 izan da;

2. gehien hautetsi den arrazoia izan da kanonaren formulazio xinple bat, honela adierazia zena: «Euskaraz aditza atzean jartzen delako»; arrazoi horrek jaso ditu adostasunik gehienak: erantzun guzien $\% 28$ an agertu da hautu hori;

3. hona aukeran emaniko bertze arrazoiek jaso dituzten atxikimendu mailak:

a) irizpide gramatikal «erlatiboak» erantzunen \%23,2 bildu du (honela formulatua: «Hautatu dudana euskaraz jatorragoa delako, euskara hobea delako»);

b) irizpide gramatikal «puruak» jaso du iritzien \%20,5 (inkestan honela formulatua: «Bestea (hautatu ez dudana) euskaraz ez delako zuzena»);

c) irizpide pragmatikoak (hots: «Hautatu dudana errazago irakurtzen/ulertzen delako») beretu du erantzunen \%14,9a;

d) honako arrazoi hau, «Hautatu dudana idatzian hobeto dagoelako (ahozkoan bestea ere onartuko nuke)», erantzunen \%10,4an agertu da;

e) azkenik, inkestan formalki aukeran eskainiriko erantzunez at, bertze arrazoi batzuk agertu dira erantzun guzien \%2,9an (honela formulatua zen inkestan: «Beste arrazoi batengatik - esan mesedez arrazoia-»). 
Ondoan datozen 2. grafikoan eta 3. koadroan ikus daitezke erantzun horiek laburturik.

\section{Hautespenaren arrazoiak}

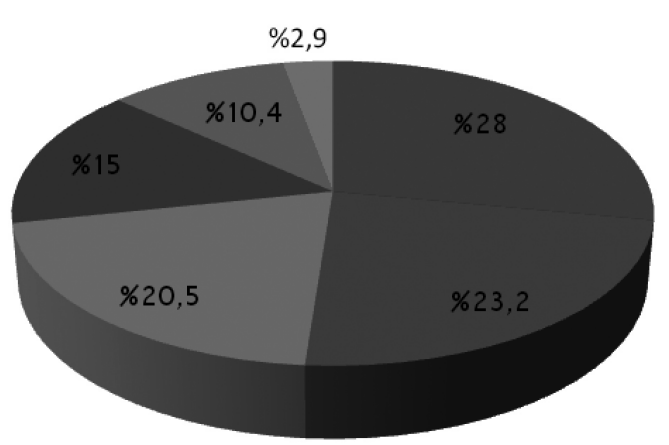

— Euskaraz aditza atzean jartzen delako

- Hautatua euskara hobea delako

- Bestea euskaraz ez delako zuzena

- Hautatua errazago ulertzen delako

- Hautatua idatzian hobeto dagoelako

- Beste arrazoiren batengatik

2. grafikoa

Ikasleen hautespenaren arrazoiak

3. koadroa

Eginiko hautuak justifikatzeko adieraziriko arrazoiak (\%)

\begin{tabular}{lc}
\hline Hautespena egiteko arrazoiak (bilduriko arrazoi guzien kopurua: 5.762) & $\begin{array}{c}\text { Erantzunen } \\
\text { kopurua } \\
(\%)\end{array}$ \\
\hline 5. Euskaraz aditza atzean jartzen delako & 28,0 \\
\hline 2. Hautatu dudana euskaraz jatorragoa delako, euskara hobea delako & 23,2 \\
\hline 1. Bestea (hautatu ez dudana) euskaraz ez delako zuzena & 20,5 \\
\hline 3. Hautatu dudana errazago irakurtzen/ulertzen delako & 15,0 \\
\hline $\begin{array}{l}\text { 4. Hautatu dudana idatzian hobeto dagoelako (ahozkoan bestea ere } \\
\text { onartuko nuke) }\end{array}$ & 10,4 \\
\hline 6. Beste arrazoi batengatik (esan mesedez arrazoia): & 2,9 \\
\hline
\end{tabular}




\subsection{Gogoeta, ondorioak eta geroko iker-lana}

Bertze ikersaio batzuetan lehenago agerturiko datuetan bezala, honetan ere ikusi dugu joera nabari-nabaria nahiago izateko erranaldiko elementuak ordenatu nola-eta atzerakarga handiko hurrenkerak sortuz. Bazterrera uzten dira, berriz, bertze hurrenkera batzuk balio lezaketenak gibelkarga arintzeko. Joera horren arrazoia izan daiteke bizirik eta bizkor dagoela eredu idealista-idiosinkratikoan oinarrizkoa zen irizpide bat. Eredu idealista-idiosinkratiko delakoak defenditzen zuen ezen atzerakarga handia sortzen zuten hizkuntza-baliabide batzuk euskararenak zirela guziz bereziki, eta euskara bereizten zutela bertze hizkuntzetatik, eta arrazoi horrexengatik hobetsi eta sustatu behar zirela euskal prosaren eredu gisa. Gaur egun, ordea, joera hori analizatzen eta kritikatzen da, eta indarra galtzen ari bide da maila teorikoan, eta hortaz eboluzio prozesu batean ibiliko litzateke. Gure iduriko badira datuak pentsatzeko gaur egun joera handiagoa ari dela garatzen baliabide linguistikoen balioa edo/eta egokitasuna neurtzeko nola-eta baliabide horiek duten gaitasunaren arabera modu efizientean komunikatzeko (Maia \& Larrea, 2013; Maia, 2014, 2015a). Ustea dugu orobat ezen atzerakarga txikiagoko hurrenkerak erabiltzeko jaidurak lagundu lezakeela eraikitzen euskal prosa-eredu prozesatu-errazago bat, eta hori bereziki baliozkoa izanen litzateke prosa logiko-diskurtsiboaren eremuan, izan ere horretan nahiko ohikoa izaten baita zenbapaiteko luzerako erranaldiak ibiltzea, eta beraz aisago nabarituko baita horietan atzerakargaren afera, eta erabakigarriagoa izanen baita mezua gradualki eta efizienteki ulertzeko.

Ohartzen gara, bertzalde, ez daitekeela ondorioztatu ezen lan honetan inkestatu ditugun pertsonek egiazki eta zehazki erabiliko dituztenik beren hizkuntza-ekoizpen errealetan hain zuzen gure ikerlanean inkestaren ondorioz agertu dituzten irizpideak. Izan ere, jabetzen gara ikersaio hau bildua dela inkestatuek erakusten duten «ezagutza deklaratiboa»ren eremuan, eta zehatzago, neurri handi batean, «ezagutza akademikoan» ${ }^{13}$. Hau da, inkestatuek irizpide horiek erabiliko lituzkete beren jakintza ohartuaren eremuan, eta jakintza hori nahiko modu fokalizatuan erabiliko lukete inkestari erantzuteko orduan. Baina, jakina, jakintza horren ondorioz erabiltzen diren irizpide «ohartuek» edo «elaboratuek» ez dute zeren bat etorri zehazki beren praktika bat-bateko edo espontaneoarekin, hizkuntza egiazki erabiltzen dutenean.

Bertzalde, inkestatuek beren hautuen arrazoiak erakusteko orduan azaldu dituzten iritziak direla-eta, ez zaigu oso harrigarria gertatu zein izan den atxikimendu gehien jaso duen erantzuna («euskaraz aditza atzean jar-

13 «Ezagutza deklaratiboa» eta «ezagutza akademikoa» delakoaz, ikus HABE-Europako Kontseilua 2005: 30 eta hurr., eta 161. 
tzen delako»), zeren azken batean formulazio hori nahiko tipikoa izan baita noiz-eta eredu idealista-idiosinkratikoa izan denean ereduzko erreferentzia nagusia. Bai iduritu zaigu deigarria joera horren indar handia gure inkestan. Izan ere, gisa honetako bertze ikersaio batzuetan, prosa logiko-diskurtsiboan hizkuntzalari adituak diren batzuek erakutsi dute joera atzerakarga txikiagoko hurrenkerak hobesteko (Maia \& Larrea, 2013; Maia, 2015a, 2015 b), eta gure iduriko komeni litzateke ideia horiek eztabaidatzea eta (beharbada) hedatzea hizkuntzarekin lanean ari diren profesionalen artean. Gure ustez, horrek aukera hobeak emanen lizkioke euskarari hiztunek hizkuntza hori «desira» edo hauta dezaten ingurune gero eta eleaniztunago batean.

Gogoan hartzekoa da halaber ezen ikerketa hau Lehen Hezkuntzako irakasle-gaien artean egin dela, eta maila horretako ez ezik bertze maila guzietako irakasleek, unibertsitatekoek barne, eragin nabaria izanen dutela euskararen prosa etorkizunean nola garatuko den. Horregatik iduritzen zaigu jakin behar dugula hobeki zer irizpide dabiltzan irakasleen artean, maila guzietan, testu mota eta genero desberdinetan, modu horretan gai garrantzitsu honetan iritziak eta jarduerak eguneratzeko, hartarako beharra sumatuz gero.

Betiere gogoan dugu euskara gero eta ingurune eleaniztunago batean bizi beharra izanen dela etorkizunean (Gorter, Zenotz \& Zenotz, 2014; Gorter et alii, 2014). Horrelako ingurune batera egokitu beharra ageri da dagoeneko hezkuntza-sistemaren ezaugarriei begiratuz (Guasch, 2007) eta baita ere erreparatuz administrazioek nolako orientabideak argitaratzen dituzten curriculumaren bidez (adibidez, EAEri dagokionez ikus: Eusko Jaurlaritza. Hezkuntza, Hizkuntza Politika eta Kultura Saila, 2016; eta Nafarroako Foru Komunitateaz: Nafarroako Gobernua, 2014). Testuinguru hori kontuan harturik, eginahal berezia egin behar da ahalik eta komunikagarritasun handiena emateko euskarari, eta zeregin horretarako kontuan hartu beharko dira berrikuntza eta tradizioa: zenbaitetan beharbada hizkuntz baliabide ezezagunagoak probatu edo hedatu beharko dira prosa efizientea garatzeko, eta aldi berean tradizioaren lotura-lana ere hagitz kontuan hartzekoa izanen da egiazko euskara-erabiltzaileek eduki diezaioten atxikimendua eta leialtasuna hizkuntzari. 


\begin{abstract}
This article addresses the issue of the order of the elements in Basque sentences and the so-called rear-burden. The predominant trend over the last $20^{\text {th }}$ century claimed that the order of the elements in Basque differs completely from the one in the surrounding languages. The success achieved by this view has often led to develop a highly/heavily rear-burdened model pattern in Basque prose. However, over the last few years various proposals have been put forward aiming at organising sentences with a slighter rear-burden, although there is little information about the spread of this tendency among users of the Basque language. In this context, two kinds of information have been gathered through this research: on the one hand, the extent of the influence of the so-called «rear burden» on a sample of university students of Primary Teacher Degree; on the other, the reasons why they show this tendency. The outcomes show that respondents prefer highly rear-burdened sentences to other ways of organising the elements, and that the simplistic idea that verb in Basque has to be put at the end of the sentence stays still strong.
\end{abstract}

Keywords: Basque language, written prose, word order, rearburden, empirical research, Primary Education.

El presente artículo trata acerca del orden de los elementos de la oración en vasco. La corriente predominante en el pasado siglo ha defendido que el orden modélico de los elementos en euskera es totalmente diferente del utilizado en las lenguas de su entorno. El éxito de esa corriente frecuentemente ha llevado a desarrollar una prosa de muy elevada retrocarga. Sin embargo, en los últimos años se han presentado diferentes propuestas que proponen organizar las oraciones con una retrocarga más reducida, aunque se dispone de poca información acerca de la extensión de esa tendencia entre los usuarios de la lengua. En ese contexto, en este trabajo se presentan dos tipos de datos: por una parte, el grado de influencia del fenómeno de la retrocarga en una muestra de estudiantes universitarios del Grado de Educación Primaria; y por otra, las razones en las que se sustenta la tendencia mostrada. Los resultados muestran, por un lado, que las personas encuestadas han preferido como modelo oraciones de alta retrocarga frente a secuencias organizadas de otro modo, y por otro, que aún se mantiene vigente la idea simplista de que en euskera el verbo se coloca en la parte final de la oración.

Palabras clave: Euskera, prosa escrita, orden de las palabras, retrocarga, estudio empírico, Educación Primaria. 
Cet article aborde la question de l'ordre des éléments dans les phrases basques et le phénomène dit «post-charge». La tendance dominante au cours du 20e siècle prétendit que l'ordre des éléments en basque diffère complètement de celle dans les langues environnantes. Le succès obtenu par ce point de vue a conduit à développer un modèle de prose fortement "post-chargé». Cependant, au cours des dernières années plusieurs propositions ont été avancées visant à une organisation de la phrase avec une post-charge plus légère, bien qu'il y a peu d'information sur la propagation de cette tendance parmi les utilisateurs de la langue basque. Dans ce contexte, deux types d'informations ont été collectés grâce à cette recherche: d'une part, l'étendue de l'influence de la dite "post-charge»sur un échantillon d'étudiants universitaires du degré de Professorat d'Education Primaire; de l'autre, les raisons données par les étudiants pour justifier la tendance manifestée. Les résultats montrent que les répondants préfèrent des phrases avec a grande post-charge à d'autres façons d'organiser les éléments, et que la notion simpliste de que le verbe en basque doit être mis à la fin de la phrase reste encore forte.

Mots-clé : Basque, prose écrite, ordre des mots, étude empirique, éducation primaire.

\section{BIBLIOGRAFIA}

Agirre, J.M. (2013). Estilo jarraituaren alde. < http://31eskutik.com/category/ jesus-maria-agirre/ > (kontsulta: 2017-03-05).

Altonaga, K. (2015). Back to Leizarraga. Iruñea: Pamiela.

Altube, S. (1975 [1929]). Erderismos (2. arg.). Bilbo: Cinsa.

Amuriza, X. (2010). Euskara batuaren bigarren jaiotza. Bilbo: Lanku.

Amuriza, X. (2012). Zazpi ebidentzia birjaiotzarako. Bilbo: Lanku

Aristegieta, X. (2009). Euskarazko testuen komunikagarritasun-problema larriak. Senez, 37, 103-141.

Esnal-Euskaltzaindia. Jagon Saila. (2011). Hitz-ordena. Erabilera estrategikoa. Bilbo: Euskaltzaindia.

Euskaltzaindia. (1987). Euskal Gramatika. Lehen Urratsak-I. Eranskina. Bilbo: Euskaltzaindia.

Euskaltzaindia. (1991). Euskal Gramatika. Lehen Urratsak 1. Bilbo: Euskaltzaindia.

Eusko Jaurlaritza. Hezkuntza, Politika eta Kultura Saila. (2016). 236/2015 Dekretua, abenduaren 22koa, Oinarrizko Hezkuntzaren curriculuma zehaztu eta Euskal Autonomia Erkidegoan ezartzen duena. URL: https://www.euskadi.eus/ y22-bopv/eu/bopv2/datos/2016/01/1600141e.shtml (kontsulta: 2017-03-06)

Garzia, J. (2014). Esaldiaren antolaera. Funtzio informatiboak gako. Bilbo: EHUAZ. 
Gorter, D.; Zenotz, V. eta Cenoz, J. (2014). Introduction: Minority Language Education Facing Major Local and Global Challenges. In D. Gorter.; V. Zenotz; J. Cenoz (argit.), Minority Languages and Multilingual Education. Bridging the Local and the Global. Dordrecht: Springer, 1-9.

Gorter, D.; Zenotz, V.; Etxague, X. eta Cenoz, J. (2014). Multilingualism and European Minority Languages: The Case of Basque. In D. Gorter; V. Zenotz; J. Cenoz (argit.), Minority Languages and Multilingual Education. Bridging the Local and the Global. Dordrecht: Springer, 201-220.

Guasch, O. (2007). La educación multilingüe: un reto para el profesorado. Cultura y Educación, 9, 135-147.

Habe-Europako Kontseilua. (2005). Hizkuntzen Europako erreferentzia marko bateratua. Vitoria-Gasteiz: EJAZN.

Hidalgo, V. (1995). Hitzen ordena euskaraz. Bilbo: UEU.

Hidalgo, V. (2002). Hitzen ordena esaldian. Senez, 25, 75-109. <http://www .eizie. org/Argitalpenak/Senez/20021201/hidalgo> (kontsulta: 2017-03-16).

Iurrebaso, I.-Soziolinguistika Klusterra. (2014). Udalerri euskaldunak EAEn: Egoera eta bilakaera, 1981-2011. Hurbilpen deskriptiboa zentsuetako datuen ustiaketaren bidez.URL: http://www.uema.eus/wp-content/uploads/2015/02/1UEMA-TXOSTENA-2014-05-26.pdf (kontsulta: 2017-03-17).

Kaltzakorta, M. (2007). Prosa komunikagarriago egiten. Zenbait proposamen. Bilbo: UEU.

Kaltzakorta, M. (2012). Zelan ordenatu egoki informazioa testuetan-I. Lekeitio, Udal batzuek lagunduta.

Laka, I. (1996). A Brief Grammar of Euskara. The Basque Language. Bilbo: UPV/ EHU.

Maia, J.; Larrea, K. (2013). Hitzen hurrenkera gogortuegia erabiltzen ote dugu idatzian?. In P. Salaburu; X. Alberdi (arg.), Iñaki Ugarteburu. Terminologia Jardunaldiak 2013. Bilbo: UPV/EHU-Euskararen Institutua, 85-97.

Maia, J. (2014). Euskal hitz-ordenaren norabidea: idealismo ideologikotik pragmatismo komunikatiborantz. Fontes Linguae Vasconum, 117, 121-168.

Maia, J. (2015a). Hacia una reducción de la retrocarga en euskera. In O. Cruz Moya, M. de la Torre García, F. Molina Díaz (arg..), Lingüística Aplicada: industrias de la lengua y cambio social. Sevilla: Universidad Pablo de OlavideAESLA. URL: <http://cvc.cervantes.es/lengua/eaesla/pdf/01/45.pdf> (kontsulta: 2017-03-14).

Maia, J. (2015b). Atzerakarga handiagoa nahi dute gazteek? Uztaro, 95, 51-71.

Mendizabal, M. (2014). Hizkuntzen berdintasun komunikatiboa: mitoa ala errealitatea? Donostia: Utriusque Vasconiae.

Mitxelena, K. (2011 [1981]). Galdegaia eta mintzagaia euskaraz. In Lakarra, J.A. (apail.). Luis Mitxelena Obras Completas VII. ASFV 'Julio de Urquijo', LX: 335-361.

Nafarroako Gobernua. (2014). 60/2014 FORU DEKRETUA, uztailaren 16koa, Nafarroako Foru Komunitatean Lehen Hezkuntzako curriculuma ezartzen duena». URL: http://www.navarra.es/home_eu/Actualidad/BON/ Boletines/2014/174/Anuncio-0/ (kontsulta: 2017-03-06)

Rubio, J. (2002). Euskararen garabideak. Irun: Alberdania.

Sarasola, I. (2016). Bitakora kaiera. Donostia: Erein. 
Zubimendi, J.; Esnal, P. (1993). Idazkera-liburua. Vitoria-Gasteiz: Eusko Jaurlaritza-Kultura Saila.

\section{1. eranskina. HAUTESPENA EGITEKO ARRAZOIAK NOLA FORMULATUAK ZIREN}

Zergatik egin duzu aukera hori? (erantzun bat baino gehiago aukeratu daiteke)

1. Bestea (hautatu ez dudana) euskaraz ez delako zuzena.

2. Hautatu dudana euskaraz jatorragoa delako, euskara hobea delako.

3. Hautatu dudana errazago irakurtzen/ulertzen delako.

4. Hautatu dudana idatzian hobeto dagoelako (ahozkoan bestea ere onartuko nuke).

5. Euskaraz aditza atzean jartzen delako.

6. Beste arrazoi batengatik (esan mesedez arrazoia). 